\title{
Perbandingan Kemampuan Berpikir Kritis Matematika Antara Siswa Yang Diajar Menggunakan Model Pembelajaran Student Facilitator And Explaining (SFAE) dan Ekspositori di Kelas VIII MTs Negeri Jember 1 (Comparison of Critical Thinking Ability of Mathematics Between Students
Who are Taught Using SFAE and Expository Learning Model in VIII Grade
MTS Negeri Jember 1)
}

\author{
Ayu Zulfiah Hasan, Dinawati Trapsilasiwi, Susi Setiawani \\ Program Studi Pendidikan Matematika, Jurusan Pendidikan MIPA, FKIP, Universitas Jember \\ Jln. Kalimantan 37, Jember 68121 \\ E-mail:_dinawati.fkip@unej.ac.id
}

\begin{abstract}
Abstrak
Penelitian ini bertujuan untuk mengetahui perbedaan kemampuan berpikir kritis matematika antara siswa yang diajar menggunakan model pembelajaran SFAE (Student Facilitator And Explaining) dan siswa yang diajar menggunakan model pembelajaran ekspositori di kelas VIII MTs Negeri Jember 1. Rancangan penelitian yang digunakan dalam penelitian ini adalah Static Group Comparison. Adapun populasi pada penelitian ini adalah siswa kelas VIIID, VIIIE, VIIIF, dan VIIIG Mts Negeri Jember 1 tahun ajaran 2015/2016, yaitu sebanyak 151 siswa. Penentuan responden dilakukan dengan cara menguji homogenitas terhadap populasi untuk mengetahui kelompok yang mempunyai variansi sama. Uji homogenitas dari 4 kelas tersebut menggunakan Analisis Varian (ANOVA) dengan F hitung sebesar 0,075 dan nilai signifikan sebesar 0,974. Dapat disimpulkan bahwa keempat kelas homogen. Nilai yang digunakan untuk uji homogenitas adalah nilai ulangan umum semester ganjil tahun ajaran 2015/2016. Setelah dinyatakan homogen, dilanjutkan dengan mencari 2 kelas masing-masing sebagai kelas eksperimen dan kelas kontrol. Didapat kelas VIII F sebagai kelas eksperimen yang akan menerapkan model pembelajaran SFAE dan kelas VIII G sebagai kelas kontrol yang akan menerapkan model pembelajaran ekspositori. Data kemampuan berpikir kritis matematika dikumpulkan melalui tes uraian yang berjumlah 4 soal. Berdasarkan hasil analisis data dan pengujian hipotesis yang diajukan dengan menggunakan uji Mann-Whitney menunjukkan hasil signifikan yang dapat dilihat dari hasil P.Sig (2-taled) untuk soal nomor 1 sebesar 0,013 , soal nomor 2 sebesar 0,000 , soal nomor 3 sebesar 0,019 , dan soal nomor 4 sebesar 0,005 . Nilai dari masingmasing soal menunjukkan bahwa Psig (2-tailed) $>0,025$ yang dapat disimpulkan bahwa ada perbedaan yang signifikan antara kemampuan berpikir kritis matematika siswa kelas VIII Mts Negeri Jember 1 yang diajar menggunakan model pembelajaran SFAE dengan yang diajar menggunakan model pembelajaran ekspositori.
\end{abstract}

Kata Kunci: Model Pembelajaran SFAE, Model Pembelajaran ekspositori, Kemampuan Berpikir Kritis

\section{Abstract}

This research was aimed to know the difference of critical thinking ability of mathematics between the students who are taught using SFAE (Student Facilitator And Explaining) and expository learning model in VIII grade MTs Negeri Jember 1. Research design used was Static Group Comparison. The population of this research was students in grade VIIID, VIIIE, VIIIF, VIIIG 2015/2016 academic year as many as 151 students. The respondents were determined using homogeneity test to population. It was done to know group who had the same variant. The homogeneity test of four groups used Varian Analysis (ANOVA) with F count 0,075 and significant score 0,974. It could be conclude that the four clases were homogeny. The scores used for homogeneity test were the scores of first semester final test 2015/2016 academic year. Having stated homogeny, it was continued by looking for two classes as experiment class and control class. It was found that VIII F grade was as experiment class which applied SFAE learning model while VIII G grade as control class which applied expository learning model. The data of critical thinking mathematics ability were collected through essay test covering 4 questions. Based on the result of data analysis and hypotheses test proposed by using Mann-Whitney showed that significant result of P.Sig (2-tailed) for question number 1 was 0,013, question number 2 was 0,000, question number 3 was 0,019, and question number 4 was 0,005. The score of each question showed that P.Sig(2-tailed)>0,025. It could be concluded that there was significant difference between critical thinking mathematics ability of the students grade VIII Mts Negeri Jember 1 who were taught using SFAE and expository learning model.

Keywords: SFAE Learning Model, Expository Learning Model, Critical Thinking Ability

\section{Pendahuluan}

Pembelajaran adalah proses interaksi siswa dengan guru dan sumber belajar pada suatu lingkungan belajar. Pembelajaran yang berkualitas sangat tergantung dari motivasi dan kretifitas guru. Target belajar dapat diukur melalui perubahan sikap dan kemampuan siswa melalui proses belajar. Desain pembelajaran yang baik, ditunjang fasilitas yang memadai, ditambah dengan kreatifitas guru akan membuat siswa lebih mudah mencapai target dalam belajar.

Salah satu mata pelajaran yang perlu mendapat perhatian dalam meningkatkan kualitas pembelajaran adalah pelajaran matematika. Banyak siswa yang merasa kurang mampu dalam mempelajari matematika, karena matematika dianggap sulit dan sebagian besar banyak siswa yang tidak menyukainya, sehingga matematika menjadi momok bagi 
mereka.

Hakekat pembelajaran matematika mempunyai dua arah pengembangan, yaitu pengembangan untuk kebutuhan masa kini dan masa yang akan datang [4]. Pengembangan kebutuhan masa kini yang dimaksud adalah pembelajaran matematika mengarah pada pemahaman konsep-konsep yang diperlukan untuk menyelesaiakn masalah matematika dan ilmu pengetahuan lainnya. Sedangkan yang dimaksud dengan kebutuhan di masa yang akan datang adalah terbentuknya kemampuan nalar dan logis, sistematis, kritis, dan cermat serta berpikir objektif dan terbuka. Hal tersebut tak luput dari keterkaitan berpikir kritis dalam proses pembelajaran untuk mempersiapkan siswa agar menjadi pemecah masalah yang tangguh, pembuat keputusan yang matang, dan orang yang tak pernah berhenti belajar.

Kemampuan dalam berpikir kritis memberikan arahan yang tepat dalam berpikir dan bekerja, dan membantu dalam menentukan keterkaitan sesuatu dengan yang lainnya lebih akurat. Kemampuan berpikir kritis bisa ditransformasikan melalui proses pembelajaran di kelas. Pembelajaran matematika memiliki peranan yang strategis dalam menumbuhkan kemampuan berpikir kritis siswa.

Kemampuan berpikir kritis, dalam pandangan Robert merupakan kemampuan yang masuk akal dan reflektif yang berfokus untuk memutuskan apa yang mesti dipercaya atau dilakukan [2]. Pada proses pembelajaran, siswa tidak boleh hanya menyerap ilmu dari guru saja, tanpa diberi kesempatan untuk bertanya, melakukan penilaian atau investigasi. Namun alangkah baiknya jika seorang guru memberi kesempatan belajar dengan melibatkan siswa secara aktif dan efektif dalam proses pembelajaran, agar siswa dapat mengembangkan kemampuan berpikir kritisnya sehingga dapat memecahkan suatu persoalan melalui berbagai jalan yang mula-mula tidak jelas akhirnya menjadi jelas, dimengerti dan dipahami. Pada penelitian ini, ruang lingkup kemampuan berpikir kritis meliputi investigasi konteks dan spektrum masalah, merumuskan masalah matematika, mengembangkan konsep jawaban dan argumentasi yang reasonable, dan melakukan evaluasi [5].

Selain itu juga, pembelajaran matematika yang biasa digunakan oleh guru adalah model pembelajaran ekspositori hanya untuk melatih kemampuan dasar matematika siswa saja. Biasanya dimulai dengan penjelasan konsep disertai contoh, lalu dilanjutkan dengan latihan soal matematika. Siswa yang terbiasa dengan model pembelajaran tersebut akan mengalami kesulitan jika soal dirubah sedikit saja dari contoh soal yang dijelaskan karena siswa cenderung menghafal langkah-langkah penyelesaian tanpa memahami permasalahan yang diberikan dengan baik. Model pembelajaran ini didominasi oleh penyajian masalah tertutup yang disajikan secara terstruktur sehingga hanya memiliki satu jawaban yang benar dan satu cara penyelesaian. Apabila kegiatan pembelajaran ini dilaksanakan secara terus -menerus maka akan berdampak buruk bagi perkembangan kompetensi siswa.

Langrehr menyatakan bahwa pertanyaan-pertanyaan yang mencakup pemikiran kritis biasanya memiliki lebih dari satu jawaban yang tepat. Proses pembelajaran ekspositori kurang menuntut keaktifan siswa dalam mengkontruksi ilmu pengetahuan dan tidak akan mampu mengembangkan kemampuan berpikir siswa secara optimal, terutama kemampuan berpikir kritis.

Salah satu model pembelajaran yang dapat mendukung keaktifan siswa dalam melatih kemampuan berpikir kritis matematika dan dapat mengemukakan pendapat dalam proses pembelajaran adalah model pembelajaran SFAE (Student Facilitator And Explaining). Model pembelajaran SFAE merupakan rangkai penyajian materi ajar yang diawali dengan penjelasan secara terbuka, memberi kesempatan siswa untuk menjelaskan kembali kepada rekan-rekannya, dan diakhiri dengan penyampaian semua materi kepada siswa [3]. Kelebihan model pembelajaran SFAE yaitu (a) membuat materi yang disampaikan lebih jelas dan konkret; (b) meningkatkan daya serap siswa karena pembelajaran dilakukan dengan demonstrasi; (c) melatih siswa untuk menjadi guru, karena siswa diberi kesempatan untuk mengulang penjelasan guru yang telah di dengar; (d) memacu motivasi siswa untuk menjadi yang terbaik dalam menjelaskan materi ajar; dan (e) mengetahui kemampuan siswa dalam menyampaikan ide atau gagasan. Dengan demikian proses pembelajaran matematika yang menerapkan model pembelajaran SFAE diharapkan dapat meningkatkan kemampuan berpikir kritis matematika siswa.

Salah satu masalah di berbagai sekolah khususnya MTs Negeri Jember 1 adalah masih rendahnya siswa dalam menyerap materi pelajaran yang disajikan oleh guru. Hal ini berdasarkan pada observasi awal yang dilakukan, bahwa model pembelajaran yang dilaksanakan masih menggunakan model pembelajaran ekspositori yang didominasi oleh guru dan tidak memberikan akses bagi siswa untuk berkembang secara mandiri melalui proses berpikir, khususnya berpikir kritis.

Berdasarkan uraian dan alasan diatas, peneliti bermaksud melakukan penelitian dengan judul, "Perbandingan Kemampuan Berpikir Kritis Matematika Antara Siswa Yang Diajar Dengan Model Pembelajaran SFAE (Student Facilitator And Explaining) dan Ekspositori Di Kelas VIII MTs Negeri Jember 1.

\section{Metode Penelitian}

Jenis penelitian ini merupakan jenis penelitian eksperimental. Tujuan penelitian eksperimen adalah untuk mengetahui pengaruh atau hubungan sebab akibat dengan cara membandingkan hasil kelompok eksperimen yang diberikan perlakuan dengan kelompok kontrol yang tidak diberi perlakuan. Penelitian ini menggunakan eksperimen semu (quasi experiment), yaitu menguji variabel bebas dan variabel terikat yang dilakukan terhadap sampel kelompok eksperimen atau kontrol .

Populasi dalam penelitian ini adalah siswa non unggulan kelas VIII MTs Negeri Jember 1 tahun ajaran 2015/2016. Jumlah siswa adalah 151 orang yang tersebar dalam 4 kelas, yaitu kelas VIIID, VIIIE, VIIIF, dan VIIIG. Sebelum menentukan sampel, populasi di uji kehomogenannya. Pada 
penelitian ini uji homogenitas dilakukan terhadap 4 kelas berdasarkan nilai ulangan umum matematika. Karena keempat kelas tersebut dinyatakan homogen yaitu kelas VIIID, VIIIE, VIIIF, dan VIIIG, maka langkah selanjutnya adalah menentukan sampel yang digunakan dengan teknik undian. Kemudian ditentukan 2 kelas yaitu kelas ekperimen sebagai kelompok siswa yang menerima pembelajaran matematika dengan menggunakan model pembelajaran SFAE dan kelas kontrol sebagai kelompok siswa yang menerima pembelajaran matematika dengan menggunakan model pembelajaran ekspositori. Jika keempat kelas tersebut tidak homogen maka menentukan kelas kontrol dan kelas eksperimen dilakukan dengan melihat rata-rata dari keempat kelas tersebut dan dipilih kelas yang perbedaan rata-ratanya tidak terlalu jauh.

Tabel 1 Distribusi Populasi Penelitian

\begin{tabular}{|c|c|c|}
\hline No. & Sumber Populasi & Jumlah Siswa \\
\hline 1 & Kelas VIII D & 38 \\
\hline 2 & Kelas VIII E & 38 \\
\hline 3 & Kelas VIII F & 39 \\
\hline 4 & Kelas VIII G & 36 \\
\hline & Total & 151 \\
\hline
\end{tabular}

Metode yang digunakan dalam pengumpulan data pada penelitian ini adalah metode dokumentasi, metode observasi, metode wawancara, dan metode tes. Metode yang digunakan dalam pengumpulan data pada penelitian ini adalah metode dokumentasi, metode observasi, metode wawancara, dan metode tes. Metode Dokumentasi yang digunakan dalam penelitian ini adalah nilai awal yang diambil melalui nilai ulangan umum semester ganjil tahun ajaran 2015/2016. Data ini digunakan sebagai bahan untuk melakukan uji homogenitas terhadap populasi penelitian.

Observasi dilakukan pada waktu pelaksanaan pembelajaran untuk mengamati aktivitas siswa dan aktivitas guru baik di kelas eksperimen maupun di kelas kontrol. Pada penelitian ini, jenis observasi yang digunakan yaitu observasi sitematis karena pengamatan menggunakan pedoman observasi sebagai instrumen pengamatan. Selain itu, observernya terdiri atas 4 orang mahasiswa pendidikan matematika dan 1 orang guru mata pelajaran matematika.

Wawancara adalah pengajuan pertanyaan secara lisan kepada sumber data mengenai informasi yang diperlukan. Jenis wawancara pada penelitian ini menggunakan wawancara bebas terpimpin yaitu pewawancara membawa pedoman berupa garis besar tentang hal-hal yang akan ditanyakan, sedangkan pengembangannya dilakukan pada saat wawancara berlangsung. Pada penelitian ini, disiapkan pertanyaan yang bertujuan untuk mengetahui tingkat berpikir kritis matematika dalam mempelajari materi bangun datar dan tanggapan beberapa siswa mengenai materi yang diajarkan dengan menggunakan model pembelajaran ekspositori dan materi yang diajarkan dengan menggunakan model pembelajaran SFAE (Student Facilitator and Explaining).
Desain dalam penelitian ini menggunakan desian Static Group Comparison. Analisis data yang digunakan dalam penelitian yaitu uji homogenitas dan uji hipotesis.

\begin{tabular}{|c|c|}
\hline$X_{1}$ & $O_{1}$ \\
\hline$X_{2}$ & $\mathrm{O}_{2}$ \\
\hline
\end{tabular}

\section{Gambar 1 Desain Penelitian Static Group Comparison}

Uji homogenitas terhadap populasi dilakukan untuk mengetahui tingkat kemampuan awal siswa terhadap mata pelajaran matematika. Uji homogenitas dalam penelitian ini didasarkan pada nilai ulangan matematika semester ganjil tahun ajaran 2015/2016. Uji homogenitas dalam penelitian ini menggunakan analisis One-Way Anova melalui SPSS 17 For Windows. Uji Hipotesis dalam penelitian ini menggunakan uji Mann-Whitney melalui SPSS 17 For Windows karena skala data adalah ordinal.

\section{Hasil Penelitian}

- Populasi dari penelitian ini yaitu kelas VIIID, VIIIE, VIIIF, dan VIIIG. Penentuan responden dilakukan dengan cara menguji homogenitas terhadap populasi untuk mengetahui kelompok yang mempunyai variansi sama. Uji homogenitas dari 4 kelas tersebut menggunakan analisis varian (ANOVA) dengan $\mathrm{F}$ hitung sebesar 0,075 dan signifikan 0,974. dapat disimpulkan bahwa keempat kelas homogen. Nilai yang digunakan untuk uji homogenitas ini adalah nilai ulangan umum semester ganjil tahun ajaran 2015/2016. Setelah dinyatakan homogen, maka dilanjutkan dengan mencari 2 kelas masing-masing sebagai kelas eksperimen dan kelas kontrol. Didapatkan 2 sampel yaitu kelas VIIIF dan VIIIG. Dengan cara mengundi 2 kelas tersebut, maka di dapat kelas VIIIF sebagai kelas eksperimen diterapkan model pembelajaran SFAE dan kelas VIIIG sebagai kelas kontrol diterapkan model pembelajaran ekspositori.

Kelas eksperimen merupakan kelas yang proses belajar mengajarnya menggunakan model pembelajaran SFAE. Pelaksanaan pembelajaran kelas eksperimen pada tahap orientasi guru memotivasi siswa tentang pentingnya mempelajari materi bangun ruang sisi datar dan mensosialisasikan model pembelajaran SFAE. Kemudian guru menjelaskan secara umum tentang bangun ruang sisi datar. Setelah itu guru membagi siswa menjadi beberapa kelompok kecil yang heterogen dengan anggota 4-5 orang tiap kelompok, berdasarkan nilai ulangan umum semester ganjil tahun ajaran 2015/2016 dan menyebutkan fasilitator dari masing-masing kelompok. Kemudian guru membagikan kertas manila kepada masing-masing kelompok dan menugaskan siswa untuk membuat peta konsep serta memberikan latihan soal untuk dikerjakan. Sebelum membuat peta konsep, guru terlebih dahulu menjelaskan mengenai pembuatan peta konsep. Setelah selesai membuat peta konsep siswa diberi kesempatan untuk menjelaskan konsep yang telah didapat dalam diskusi kelompok dengan 
mempresentasikannya di depan kelas. Inilah salah satu hasil pembuatan peta konsep dari kelompok 8 yang telah didiskusikan bersama anggota kelompoknya.

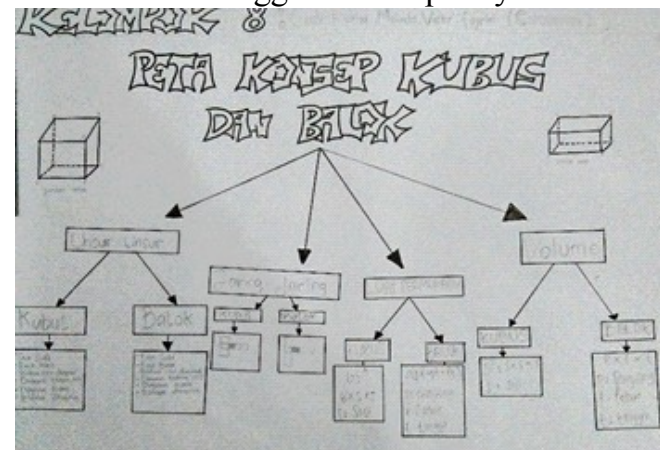

Gambar 2 Hasil Pekerjaan Siswa Dalam Pembuatan Peta Konsep

Selanjutnya pada kegiatan merangkum materi yang dipelajari, secara tidak langsung siswa akan melibatkan kemampuan berpikir kritisnya dalam membuat rangkuman karena siswa akan memilih dan membuat kaitan antara gagasan yang telah dipelajari dan memyisualisasikannya dalam bentuk gambar, simbol, ataupun notasi,

Kelas kontrol merupakan kelas yang proses belajar mengajarnya menggunakan pembelajarn ekspositori. Pelaksanaan pembelajaran pada kelas kontrol pertama-tama guru memberikan salam kepada siswa kemudian guru melakukan apersepsi yaitu menjelaskan tentang tujuan dan model pembelajaran yang akan digunakan serta mengaitkannya dalam kehidupan sehari-hari. Selanjutnya materi dijelaskan dengan memberikan beberapa contoh soal serta diberikan kesempatan kepada siswa jika ada siswa yang ingin bertanya. Selanjutnya guru memberikan latihan soal dan membimbing siswa menemukan jawaban.

Data hasil wawancara bersama seorang guru mata pelajaran matematika dan 3 orang siswa yang dipilih berdasarkan nilai tertinggi, sedang, dan rendah untuk masing-masing kelas, baik kelas kontrol maupun kelas eksperimen. Wawancara ini dilakukan oleh peneliti untuk mengetahui tanggapan dan respon mereka terhadap mata pelajaran matematika dan tanggapan mereka terhadap soal post test yang diberikan.

Dari hasil wawancara pada siswa kelas eksperimen dan kelas kontrol, mayoritas siswa menganggap matematika itu adalah pelajaran yang sulit dan tidak terlalu disenangi oleh beberapa siswa. Pada dasarnya hanya siswa yang menyukai perhitungan saja yang menyukai matematika sehingga kemampuan matematikanya cukup baik, sedangkan untuk siswa yang kesulitan dalam perhitungan cenderung tidak menyukai pelajaran matematika.

Mengenai model pembelajaran SFAE yang ditetapkan di kelas eksperimen diperoleh respon yang positif meskipun pada awalnya siswa merasa bingung dengan pembelajaran SFAE yang kaitannya dengan berpikir kritis. Siswa cenderung senang karena model pembelajaran ini lebih berpusat pada mereka, seperti diskusi bersama kelompoknya dan dapat berlatih kemampuan komunikasi dengan mempresentasikan hasil diskusi mereka di depan kelas. Untuk model pembelajaran SFAE, siswa di kelas eksperimen juga merasa mendapatkan ilmu baru yang sebelumnya tidak pernah mereka dapatkan yaitu dalam pembuatan peta konsep. Di kelas eksperimen maupun kelas kontrol, siswa juga mengetahui bahwa sebuah permasalahan dapat dikembangkan sehingga muncul permasalahan yang baru ataupun bisa diselesaikan dengan cara yang berbedabeda dan nantinya hasilnya pun berbeda-beda. Sehingga siswa tidak terpaku pada satu jawaban yang benar meskipun hal tersebut membutuhkan kerja keras siswa dalam berpikir.

Respon guru terhadap model pembelajaran SFAE juga positif. Menurut guru mata pelajaran matematika pembelajaran yang menggunakan model pembelajaran SFAE membuat siswa lebih aktif daripada siswa dikelas kontrol dikarenakan model pembelajaran SFAE yang berpusat pada siswa dan model pembelajaran ekspositori berpusat pada guru.

Data hasil observasi aktivitas guru dan aktivitas siswa ini dilaksanakan pada saat proses pembelajaran berlangsung. Observasi dilakukan oleh 5 observer yang terdiri atas guru mata pelajaran matematika yang mengobservasi aktivitas siswa. Pada penelitian ini, observer diberikan tahapantahapan pembelajaran sehingga pada saat pembelajaran observer hanya memberikan skor setiap tahapan.

Berdasarkan analisis one-way anova diperoleh $F$ hitung sebesar 0,075 dengan signifikan 0,0974. Sedangkan $F$ tabel pada perhitungan dibawah taraf signifikan $95 \%$ dengan derajat kebebasan (dk) pembilang 3 dan derajat kebebasan (dk) penyebut 147 adalah 2,67. Hasil perhitungan tersebut menunjukkan bahwa nilai $F$ hitung lebih kecil dari $F$ tabel sehingga $H 1$ ditolak dan $H O$ diterima. Maka pada uji anova $H O$ diterima atau diketahui bahwa rata-rata nilaikemampuan awal setiap kelas adalah sama. Selanjutnya memilih 2 sampel yaitu kelas $\mathrm{F}$ dijadikan sebagai kelas eksperimen dan kelas $\mathrm{G}$ dijadikan sebagai kelas kontrol dengan menggunakan teknik undian.

Untuk uji hipotesis berdasarkan permasalahan yang di analisis yaitu adakah perbedaan yang signifikan antara kemampuan berpikir kritis matematika siswa kelas VIII MTs Negeri Jember lyang diajar menggunakan model pembelajaran SFAE dengan yang diajar menggunakan model pembelajaran ekspositori. Berikut adalah hasil uji Mann-Whitney dengan satu soal mewakilkan satu indikator. Soal nomor 1 menunjukkan kemampuan berpikir kritis dalam merumuskan masalah matematika dengan indikator siswa mampu merumuskan masalah matematika agar dapat mengkontruksi berbagai kemungkinan jawaban. Dari uji Mann-Whitney menunjukkan nilai P.Sig (2-tailed) sebesar 0,013 lebih kecil dari 0,025 maka dapat disimpulkan bahwa soal nomor 1 terdapat perbedaan kemampuan berpikir kritis matematika antara siswa yang diajar menggunakan model pembelajaran SFAE dengan siswa yang diajar menggunakan model pembelajaran ekspositori. Soal nomor 2 menunjukkan kemampuan berpikir kritis dalam menginvestigasi konteks dan spektrum masalah dengan indikator siswa mampu menghasilkan berbagai pengandaian dan dapat mengembangkan berbagai masalah model masalah. Dari uji Mann-Whitney menunjukkan nilai P.Sig (2-tailed) sebesar 
0,000 lebih kecil dari 0,025 maka dapat disimpulkan bahwa soal nomor 2 terdapat perbedaan kemampuan berpikir kritis matematika antara siswa yang diajar menggunakan model pembelajaran SFAE dengan siswa yang diajar menggunakan model pembelajaran ekspositori. Soal nomor 3 menunjukkan kemampuan berpikir kritis dalam mengembangkan konsep jawaban dan argumentasi yang reasonable yang menghubungkan konsep dengan permasalahan yang dihadapi. Dari uji Mann-Whitney menunjukkan nilai P.Sig (2-tailed) sebesar 0,019 lebih kecil dari 0,025 maka dapat disimpulkan bahwa nomor 3 terdapat perbedaan kemampuan berpikir kritis matematika antara siswa yang diajar menggunakan model pembelajaran SFAE dengan siswa yang diajar menggunakan model pembelajaran ekspositori. Soal nomor 4 menunjukkan kemampuan berpikir kritis matematika dalam melakukan evaluasi dengan indikator siswa mampu membuat penilaian terhadap konteks masalah dan dapat menemukan alternatif penyelesaian lain. Dari uji Mann-Whitney menunjukkan nilai P.Sig (2-tailed) sebesar 0,005 lebih kecil dari 0,025 maka dapat disimpulkan bahwa nomor 4 terdapat perbedaan kemampuan berpikir kritis matematika antara siswa yang diajar menggunakan model pembelajaran SFAE dengan siswa yang diajar menggunakan model pembelajaran ekspositori

\section{Pembahasan}

Penelitian ini merupakan penelitian eksperimen dengan menggunakan desain Static Group Comparison yang bertujuan untuk mengkaji perbedaan kemampuan berpikir kritis matematika siswa yang diajar menggunakan model pembelajaran SFAE dan model pembelajaran ekspositori. Penelitian ini dilaksanakan di MTs Negeri Jember 1 kelas VIIID, VIIIE, VIIIF, dan VIIIG. Materi yang digunakan adalah materi tentang bangun ruang sisi datar kubus dan balok dengan menggunakan model pembelajaran SFAE dan model pembelajaran ekspositori.

Model pembelajaran SFAE adalah rangakaian penyajian materi ajar yang diawali dengan penjelasan secara terbuka, memberikan kesempatan siswa untuk menjelaskan kembali kepada rekan-rekannya, dan diakhiri dengan penyampaian semua materi kepada siswa. Model pembelajaran ini dilaksnakan secara berkelompok. Setiap kelompok terdiri dari 4-5 orang dan pembentukan kelompok dilaksanakan secara heterogen yaitu berdasarkan nilai ulangan umum matematika semester ganjil tahun ajaran 2015/2016. Siswa akan melibatkan kemampuan berpikir kritisnya dalam menemukan solusi dari permasalahan yang diberikan, dan pada setiap kelompok terdapat fasilitator yang akan bertugas untuk membantu anggota kelompoknya dalam memahami materi pelajaran dan saling berdiskusi dalam menyelesaikan permasalahan yang diberikan guru. Siswa yang ditunjuk sebagai fasilitator bersama anggota kelompoknya akan menuangkan hasil pemikirannya tersebut dalam bentuk peta konsep.

Model pembelajaran ekspositori merupakan model pembelajaran yang berpusat pada guru. Model pembelajaran ini menggunakan metode ceramah yang menyebabkan siswa sedikit pasif dalam pembelajaran.

Berdasarkan hasil analisis data dan pengujian hipotesis yang diajukan dengan menggunakan uji Mann-Whitney menunjukkan hasil yang signifikan. Hal ini dapat dilihat dari hasil perhitungan tiap soal yang mengandung tiap indikator dari kemampuan berpikir kritis. Soal 1 menunjukkan kemampuan berpikir kritis dalam merumuskan masalah matematika dengan indikator siswa mampu merumuskan masalah matematika agar dapat mengkontruksi berbagai kemungkinan jawaban hal ini dapat dilihat menggunakan uji Mann-Whitney sebesar 0,013 yang kemudian dibandingkan dengan taraf signifikan yang ditetapkan yaitu sebesar 0,025 . Karena 0,013 lebih kecil dari 0,025 maka ada perbedaan antara kelas eksperimen dan kelas kontrol untuk soal nomor 1. Soal nomor 2 menunjukkan kemampuan berpikir kritis matematika dalam menginvestigasi konteks dan spektrum masalah dengan indikator siswa mampu menghasilkan berbagai pengandaian dan dapat mengembangkan berbagai model masalah, hal ini juga dapat dilihat menggunakan Mann-Whitney sebesar 0,000 yang kemudian dibandingkan dengan taraf signifikan yaitu sebesar 0,025 . Karena 0,000 lebih kecil dari 0,025 maka ada perbedaan antara kelas eksperimen dan kelas kontrol untuk soal no 2. Soal nomor 3 menunjukkan kemampuan berpikir kritis matematika dalam mengembangkan konsep jawaban dan argumentasi yang reasonable dengan indikator siswa mampu menyusun berbagai konsep jawaban dan dapat merumuskan argumenargumen reasonable yang menghubungkan konsep dengan permasalahan yang dihadapi, hal ini dapat dilihat menggunakan Mann-Whitney sebesar 0,019 lebih kecil dari 0,025 maka ada perbedaan antara kelas eksperimen dan kelas kontrol untuk soal nomor 3. Soal nomor 4 menunjukkan kemampuan berpikir kritis matematika dalam melakukan evaluasi dengan indikator siswa mampu membuat penilaian terhadap konteks masalah dan dapat menemukan alternatif penyelesaian lain, hal ini dapat dilihat pada uji Mann-Whitney sebesar 0,005 lebih kecil dari 0,025 maka ada perbedaan antara kelas eksperimen dan kelas kontrol untuk soal nomor 4.

Dari keempat soal yang telah diujikan menggunakan Mann-Whitney maka dapat disimpulkan bahwa terdapat perbedaan kemampuan berpikir kritis matematika antara siswa yang diajar menggunakan model pembelajaran SFAE dengan yang diajar menggunakan model pembelajaran ekspositori di kelas VIII MTs. Negeri Jember 1. Selain itu juga dari uji Mann-Whitney dan faktor pendukung lainnya seperti dokumentasi, observasi dan wawancara dapat diketahui bahwa kelas eksperimen yaitu kelas $\mathrm{F}$ yang diajar menggunakan model pembelajaran SFAE lebih baik dari kelas kontrol yaitu kelas $G$ yang diajar menggunakan model pembelajaran ekspositori.

Kemampuan berpikir kritis siswa kelas eksperimen lebih baik karena dengan penerapan model pembelajaran SFAE dalam pembelajaran matematika, guru dapat mengoptimalkan partisipasi siswa dalam pembelajaran, yaitu: (1) siswa diberi kesempatan berperan sebagai fasilitator yang akan membantu guru untuk menjelaskan 
materi pelajaran kepada masing-masing anggota kelompoknya serta bersama-sama mencari informasi yang berkaitan dengan materi pelajaran kemuudian dengan proses berpikirnya siswa menemukan secara mandiri gagasangagasan yang penting dalam rangka mengembangkan pemahaman baru berdasarkan pengetahuan awal yang dimiliki sebelumnya; (2) siswa belajar dalam kelompok kooperatif yang melibatkan kemampuan berpikir kritisnya dalam menyelesaiakan soal dan setiap kelompok terdapat fasilitator yang akan bertugas memfasilitasi membantu anggota kelompoknya dalam memahami materi pelajarn; (3) siswa yang ditunjuk sebagai fasilitator bersama-sama dengan anggota kelompoknya akan menuangkan hasil pemikiran masing-masing dari mereka dalam bentuk peta konsep.

Pada pembuatan peta konsep, kemampuan berpikir kritis siswa dapat dilatih ketika siswa memahami tahapan gagasan -gagasan relevan yang telah dipilih tersebut sehingga pemahaman siswa terhadap matematika akan menjadi lebih sistematis dan terstruktur; (4) siswa diberikan kesempatan untuk menjelaskan konsep yang telah didapat dalam diskusi kelas. Selanjutnya, (5) pada kegiatan merangkum materi yang telah dipelajari, secara tidak langsung siswa akan melibatkan kemampuan berpikir kritisnya dalam membuat rangkuman kerana siswa akan memilih dan membuat kaitan antar gagasan yang telah dipelajari dan memvisualisasikannya dalam bentuk gambar, simbol, ataupun notasi.

\section{Kesimpulan dan Saran}

Penelitian perbandingan kemampuan berpikir kritis matematika antara siswa yang diajar menggunakan model pembelajaran SFAE dan ekspositori di kelas VIII MTs Negeri Jember 1 telah dilaksanakan. Berdasarkan hasil dan pembahasan pada bab sebelumnya, kesimpulan dari penelitian ini adalah ada perbedaan antara kemampuan berpikir kritis matematika (dengan beberapa indikator, yaitu menginvestigasi konteks dan spektrum masalah,merumuskan masalah matematika, mengembangkan konsep jawabandan argumentasi yang reasonable, dan melakukan evaluasi) antara siswa yang diajar menggunakan model pembelajaran Student Facilitator And Explaining (SFAE) dan ekspositori di kelas VIII MTs Negeri Jember 1.

Berdasarkan proses dan hasil penelitian perbandingan tersebut selanjutnya muncul beberapa saran dan masukan yaitu perbandingan kemampuan berpikir kritis matematika antara siswa yang diajar menggunakan model pembelajaran SFAE dan ekspositoridi kelas VIII sebaiknya dikembangkan lebih lanjutmengenai pembelajaran ini dengan menggunakan variabel lain selain kemampuan berpikir kritis atau pada materi pelajaran matematika lainnya .

\section{Ucapan Terima Kasih}

Penulis mengucapkan terima kasih kepada dosen pembimbing tugas akhir, serta kepala sekolah dan guru matematika di MTs Negeri Jember 1 yang telah membimbing selama penelitian.

\section{Daftar Pustaka}

[1] Arifin, Zainal. 2012. Penelitian Pendidikan. Bandung: PT. Remaja Rosdakarya.

[2] Fisher, Alec. 2009. Berpikir Kritis: Sebuah Pengantar. Bandung: Erlangga.

[3] Huda, Miftahul. 2013. Model-Model Pengajaran Dan Pembelajaran. Yogyakarta: Pustaka Pelajar Kencana.

[4] Somakim. 2002. Peningkatan Kemampuan Berpikir Kritis Matematis Siswa Sekolah Menengah Pertama Dengan Penggunaan Pendidikan Matematika Realistik. Forum MIPA, Volume 14, Nomor 1 Januari 2011.

[5] Sudiarta, Putu.-. Pengembangan Kompetensi Berpikir Divergen Dan Kritis Melalui Pemecahan Masalah Matematika Open-Ended. Jurnal Pendidikan dan Pengajaran IKIP Negeri Singaraja, No. 3 Th. XXXVIII Juli 2015. 